\title{
INVESTIGATION ON THE SEISMIC RESPONSE OF A LARGE MONUMENTAL COMPLEX
}

\author{
SILVIA CAPRILI ${ }^{1}$, IRENE PUNCELLO ${ }^{2 *}$ AND PERE ROCA $^{3}$ \\ 1 Department of Civil and Industrial Engineering (DICI) \\ University of Pisa \\ Largo L. Lazzarino 1, 56122 Pisa, Italy \\ e-mail: silvia.caprili@,ing.unipi.it - Web page: dici.unipi.it \\ ${ }^{2 *}$ Department of Energy, Systems, Territory and Construction Engineering (DESTeC) \\ University of Pisa \\ Largo L. Lazzarino 1, 56122 Pisa, Italy \\ e-mail: irene.puncello@ing.unipi.it - Web page: destec.unipi.it \\ ${ }^{3}$ Department of Civil and Environmental Engineering (DCEE) \\ Universitat Politècnica de Catalunya \\ Jordi Girona 1-3, 08034 Barcelona, Spain \\ e-mail: pere.roca.fabregat@upc.edu -Web page: https://deca.upc.edu
}

Keywords: Historical masonry building, monumental complex, pushover analysis, Finite Element Modelling, vulnerability assessment

\begin{abstract}
.
Historical masonry structures are characterised by a high level of seismic vulnerability, as demonstrated by recent and past seismic events. Monumental buildings, in particular, represent a very challenging topic. Their morphological evolution, characterised by transformations, aggregations and modifications developed over the centuries, have given rise to very complex structures that should be considered as structural aggregates rather than single buildings. The present paper briefly summarises the assessment of the structural performance of the monumental complex of the Certosa di Calci (Italy), by applying an in-depth multi-level and multi-disciplinary approach. The morphological evolution of the aggregate was studied by means of critical historical analysis enabling the identification of the structural units composing it. The complex was, besides, subjected to in-situ survey campaigns allowing an adequate knowledge level. Reliable FEM models were elaborated, and non-linear static pushover analyses were performed. The single structural units were initially studied as isolated buildings and then combined evaluating the influence of the in-aggregate behaviour on the overall structural response. Pushover analyses were performed for each evolution configuration, allowing results in terms of capacity curves, load factors and damage distribution. The methodology presented, although used for a specific case study, can be extended to other constructions characterised by similar complexity and features.
\end{abstract}




\section{INTRODUCTION}

Masonry structures represent the most widespread existing constructive typology in the European cultural heritage. Seismic events recently occurred evidenced the high seismic vulnerability of historical buildings, highlighting the need for detailed research on their structural response $[1,2]$. Among masonry constructions, monumental buildings represent a particularly challenging issue. These structures are characterised by a complex constructive genesis, where the transformations occurred over the centuries determine the coexistence of portions belonging to different ages. Those portions are not always easily recognisable and are often characterised by different construction techniques and by the lack of adequate connections [3]. Many monumental buildings should be considered as structural aggregates rather than as single buildings [4], composed by several Structural Units (SU) not necessarily working together in a global way [5]. To achieve reliable results from structural assessment, deep and accurate investigations are needed, based on detailed knowledge of their history and construction features [6-8]. A sufficient knowledge should be achieved on the base of a well-organised historical analysis able to reconstruct the actual morphology and accounting for the past transformations [9]. Besides, the intrinsic nature of the aggregate requires a detailed identification of its SUs in order to stablish a realistic decomposition into elementary cells mutually interacting $[10,11]$.

The present paper focuses on the investigation of the structural seismic behaviour of a portion of the Certosa di Calci monumental complex (Tuscany, Italy). An accurate multidisciplinary knowledge analysis $[12,13]$ was carried out to reconstruct the structural evolution of the aggregate. Criteria to subdivide the complex into SUs were envisaged accounting for the realisation period and
the different morphology of structural components [14-18]. Relevant SUS there then rnodelled using
the FEM approach to perform non-linear sejsmic analyses. The pushover analyses allowed a prompt
and relatively easy characteris ation of the structural behaviour and seisndic capacity. A cyitical
review of the mutual interaction between SUs is obviously needed since the morpho/ogical
evolution and the historical transformations lead to a complex mechanical collaboration among the different units constituting the aggregate. The numerical model, with all the simplifications and

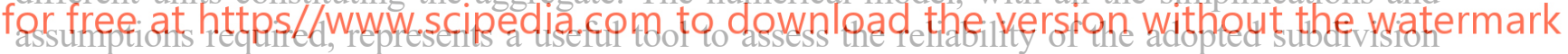

criteria. The capacity curves and damage predicted by the numerical model allows an accurate investigation and understanding of the structural behaviour of the aggregates taking into account their construction complexity. For this purpose, the elementary cells were firstly analysed as single buildings and then progressively connected with other cells to account for the aggregate morphology. Pushover analyses were thus performed in different configurations, based on the information derived from the historical analysis, in order to evaluate the influence of the interaction between SUs on the overall structural response.

\section{HISTORICAL EVOLUTION OF THE MONUMENTAL COMPLEX}

The Certosa di Calci monumental complex (Figure 1a) is located in Calci, few kilometres far from Pisa, in a strategic position in the South-Western foothill of the Monte Pisano. Benefit from the inheritance of a rich merchant of Pisa and of other private donations, the building process of the monastic complex officially started in 1366. At the beginning, the construction works proceeded fast, allowing the settlement of the first religious family only two years after the foundation. Despite that, the conclusion of the original nucleus, provided with all the spaces essential for the monks' life, could be attested only in the last decade of $14^{\text {th }}$ century. 

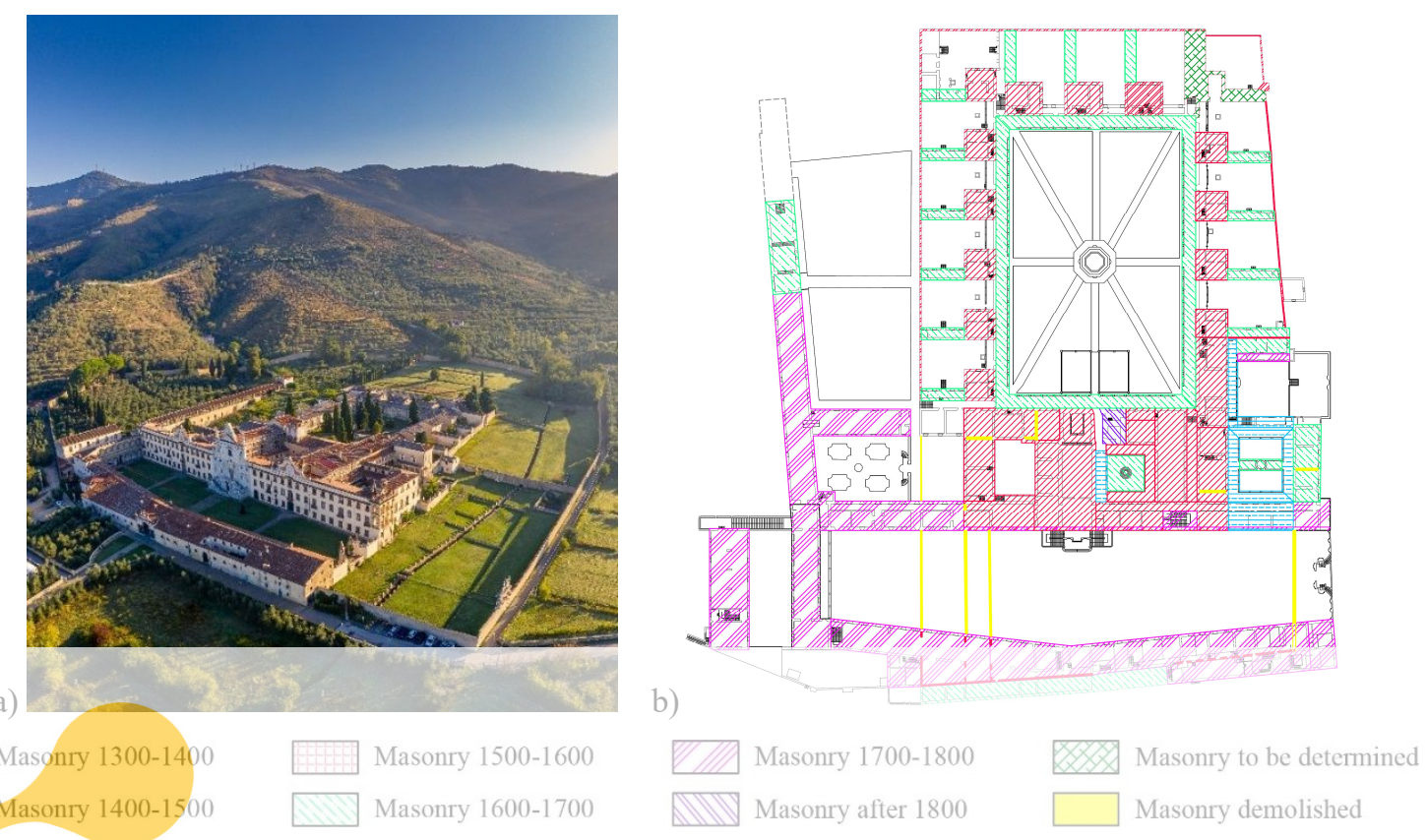

Figure 1: a) View of the Certosa di Calci. Photo by courtesy of Guglielmo Giambartolomei; b) plan of the $1^{\text {st }}$ level of the complex with identification of the macro-constructive phases according to the legend.

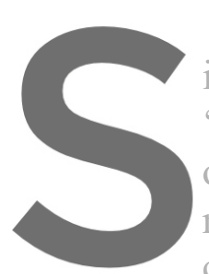

The building procass interventions (e.g. addit 'monumental' appearanc t. of the $17^{\text {th }}$ century, more most of the first nucleus cloister on the right of the
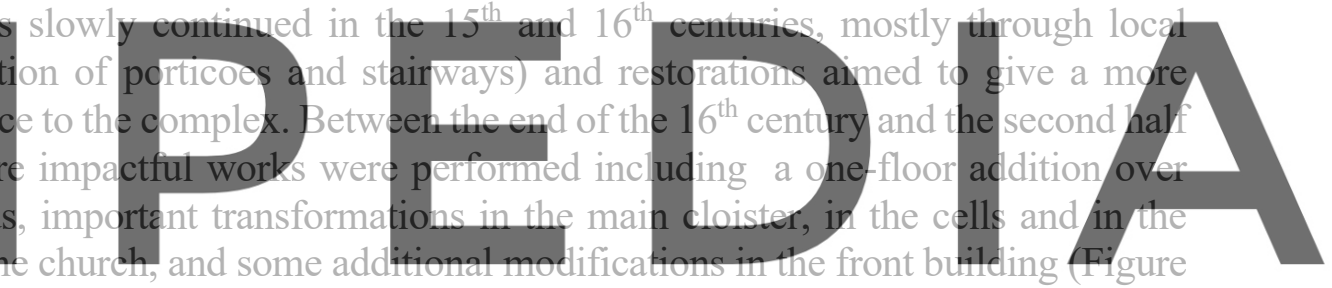

1b). Nevertheless, the biggest transformations involving Certosa di Calci took place at the end of

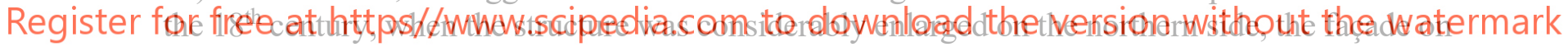
the courtyard was completed with the addition of the block on the southern corner and several other modifications were realised $[19,20]$ bringing the building to the current appearance.

\section{CERTOSA DI CALCI: STATE OF THE ART}

\subsection{General description of the building complex}

Nowadays, the monumental complex of Certosa di Calci shows an irregular shape, the result of the non-homogeneous genesis and of the gradual additions of units to the original nucleus previously mentioned. The different SUs composing the aggregate generally develop on two or three floors, according not only to the importance of the housed function, but also to their position, since the ground level is uphill towards the main cloister.

The different portions are distributed around seven courts (Figure 2), including the main courtyard facing the Church, two little cloisters on its right (i.e. 'chiostro del capitolo' and 'chiostro della foresteria'), three gardens/courts on its left and the main cloister. All the cloisters are surrounded by vaulted porticoes, while continuous façades mainly frame gardens and courts.

On the front of the complex, limiting the main courtyard on the East side, the building known 
as 'Case Basse' is located. It developed through subsequent additions to the original surrounding wall and is characterised by a large longitudinal extension with significant structural complexity mainly at the ground floor. The North side of the main court is closed by a two-level block which continues towards the garden and slightly changes its orientation following the sloping ground. Next to the above-mentioned courtyard there is another small court, delimited on the northern side by a quite regular building once housing the barn. The central wing of the monumental complex is composed of several blocks, mainly developed on three levels and organised around four open spaces with the church as central fulcrum. The main cloister shows six cells on the northern and southern side and three cells on the western ones; each cell has its own garden and presents a main squared two-level body and a rectangular one-level body added in the back. The Prior's cell is the only showing higher dimensions and more refined architectural elements.

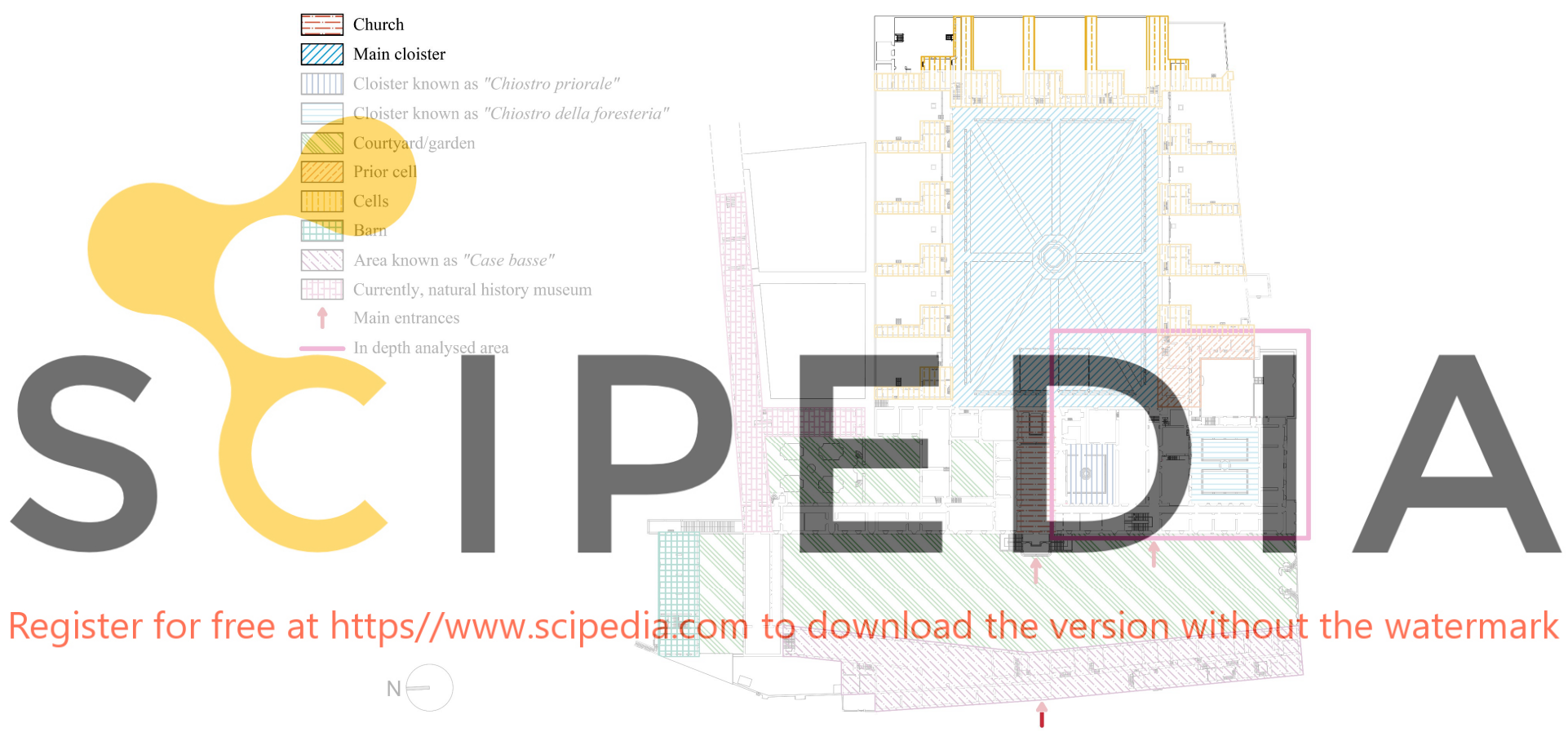

Figure 2: Plan of the first level of the monumental complex with identification of representative areas.

Different functional activities are housed inside the Certosa: offices of employees of the Pisa University are spread in different areas, mostly on the $2^{\text {nd }}$ and $3^{\text {rd }}$ floor, while the first two levels on the left of the church host museum spaces. Part of the block on the front of the main courtyard is managed by the Superintendence of Cultural Heritage, as well as part of the $1^{\text {st }}$ floor on the right of the church that is devoted to tourist visits; the cells in the main cloister are mostly used as storages or unused. Due to the large dimensions and to the high heterogeneity of the complex, the in-situ surveys and the following numerical analyses focused on the southern portion marked in Figure 2. This area is one of the most ancient and most articulated due to its highly stratified genesis.

\subsection{Geometrical and structural survey}

With the cooperation of other research groups of Pisa University, the geometry of the selected area was investigated by means of direct and indirect measurements. The latter ones 
were performed through Terrestrial Laser Scanner, able in measuring the position of a great amount of points (the so-called 'point cloud model'), later elaborated in CAD environment to produce plans and sections of all the floors with a high level of accuracy.

An extensive in-situ survey campaign was performed to deeply analyse the current structural condition. Investigations were planned to determine the geometry of structural elements, to define the consistency of walls, vaults and horizontal storeys as well as the connections among different bearing components. Different typologies of vaulted surfaces (e.g. groin, barrel and mirror vaults, some of them with lunettes), with average height between 5 and $6 \mathrm{~m}$, were surveyed in the first two floors. On the contrary, the last level mostly presented wooden storeys with interstorey height equal to about 3-4 m.

The in-situ investigations were spread homogenously around the analysed area achieving a consistent knowledge level, focusing where evident critical points or possible discontinuities were highlighted by the historical analysis (Figure 3). Concerning vertical bearing structures, the textures were analysed by the removal of $50 \times 50 \mathrm{~cm}$ plaster portions, with attention to the eventual presence of paintings to be protected. Afterwards, endoscopic investigations aiming to check the inner morphology (e.g. presence of cavities, different adjacent walls, etc.) were performed. Six typologies of masonry pattern were classified. In turn, a general lack of suitable connections between perpendicular walls was observed. No relevant correspondence among the masonry typologies and the historical construction periods was found.
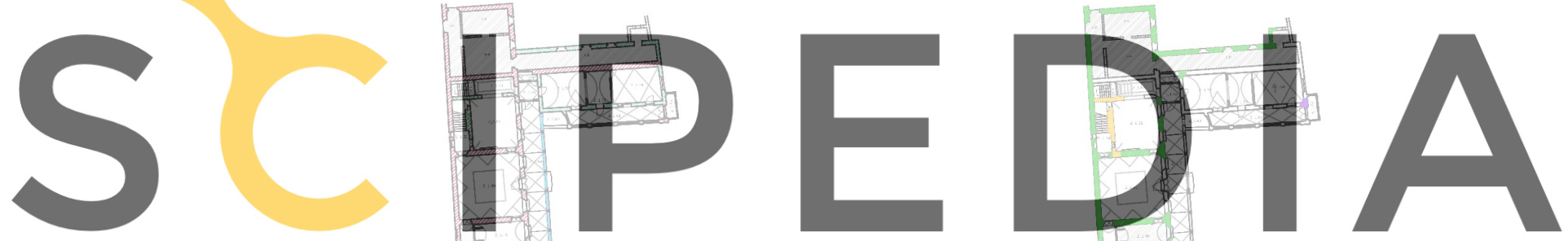

Register for free at https//Wwws scipedia.com to download the version without the watermark
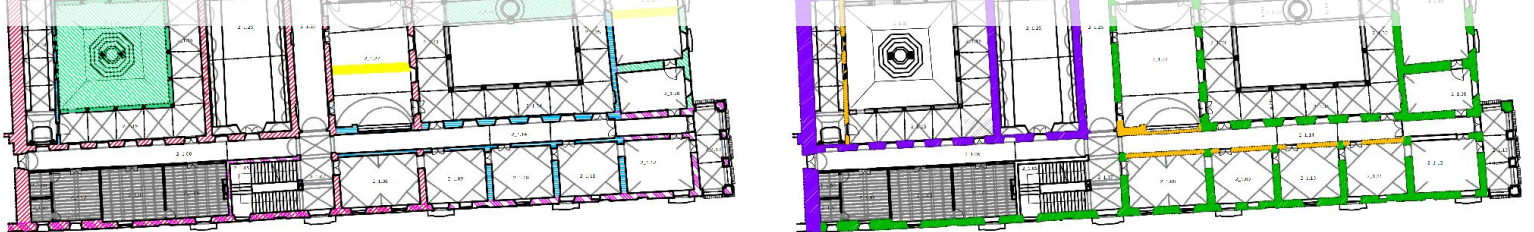

a)

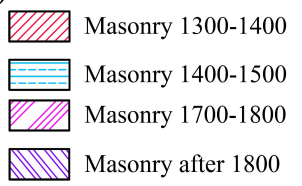

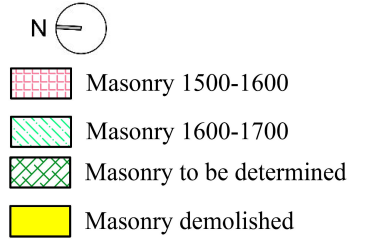

b)

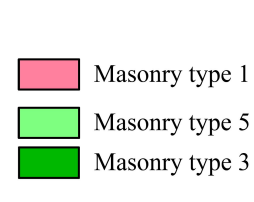

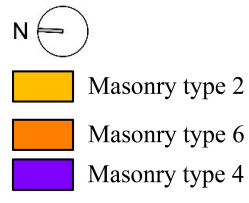

Figure 3: Plans of the first level of the selected area representing: a) the identification of the morphological evolution $b$ ) the survey of the masonry typologies.

Plaster removals and endoscopic investigations were also used for the analysis of vaulted surfaces, determining the material composing the load-bearing part, its thickness, the size and 
typology of the filling layers. Concerning horizontal storeys, the direct survey was used to determine the size of structural bearing elements and the upper stratigraphy needed to evaluate the resulting permanent loads and masses. In the case of the roof structure, consisting in timber trusses with joists directly supporting the roof covering, inspections were performed only in the accessible areas; consequently, the level of maintenance of the material was assessed thanks to specialised technologists. The survey of the cracking scenario and of the deformation pattern was besides completed both on vertical and horizontal structures; visual inspections and, where needed, removal of plaster portions were performed with the aim of identifying possible local mechanisms, settlement movement or structural deficiency to be in-depth analysed.

\subsection{Material properties}

For the masonry mechanical properties, values suggested by the current scientific literature were adopted due to the lack of experimental tests results. The masonry textures identified through the in-situ surveys were divided into two macro-categories, correspondent to the 'Muratura in pietrame disordinata' and 'Muratura in mattoni pieni e malta di calce' of the table C8.5.I of the Italian Design Code 'Circolare applicativa' [21]. The latter one was adopted also for the vaults, while for the material of the columns, identified as serena stone, the values proposed in $[22,23]$ were accounted for. Table 1 summarises the adopted material properties.

specific investigation of the state of maintenance of the iron tie-rods was performed including experimental tests to assess the effective value of tensile strains characterising each

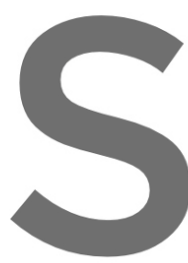
element. Concerning wood was considered maintenance problems wood class (S3) accordin
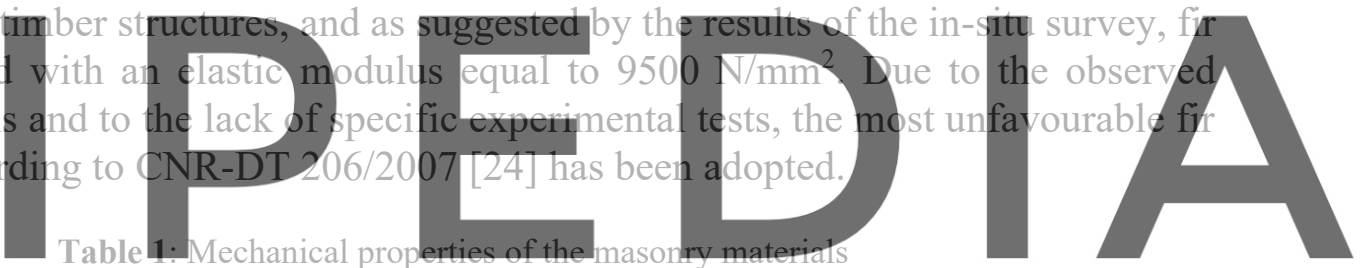

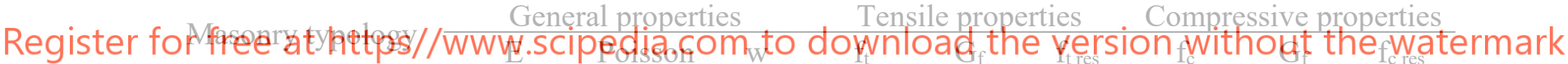

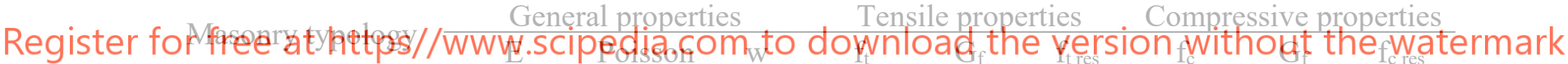

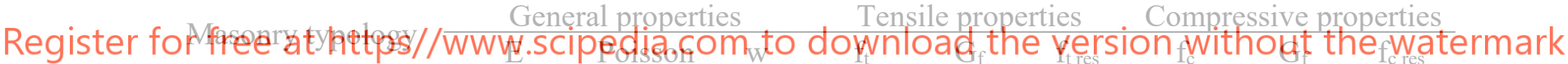

\begin{tabular}{cccccccccc} 
& $\mathrm{N} / \mathrm{mm}^{2}$ & - & $\mathrm{kN} / \mathrm{m}^{3}$ & $\mathrm{~N} / \mathrm{mm}^{2}$ & $\mathrm{~N} / \mathrm{mm}^{2}$ & $\mathrm{~N} / \mathrm{mm}^{2}$ & $\mathrm{~N} / \mathrm{mm}^{2}$ & $\mathrm{~N} / \mathrm{mm}$ & $\mathrm{N} / \mathrm{mm}^{2}$ \\
\hline Uneven masonry & 690 & 0.2 & 19 & 0.05 & 0.0050 & 0.005 & 1 & 1.60 & 0.1 \\
\hline $\begin{array}{c}\text { Masonry composed } \\
\text { of solid brick and } \\
\text { lime mortar }\end{array}$ & 1200 & 0.2 & 18 & 0.13 & 0.0097 & 0.013 & 2.6 & 4.16 & 0.26 \\
\hline Serena stone & 1581000 & 0.2 & 26.5 & 5 & 0.1253 & 0.5 & 100 & 160.00 & 10 \\
\hline
\end{tabular}

\section{NUMERICAL MODELLING AND STRUCTURAL ANALYSIS}

\subsection{General approach adopted for modelling}

To assess its structural performance, the selected portion of the Certosa di Calci was firstly disaggregated into its SUs, analysed separately and later re-assembled aiming to understand the effects of mutual interaction of the SUs due to the 'in-aggregate' behaviour. At the moment, only the two limit conditions have been considered, consisting of lack of connection and full connection. The real connection condition may be in fact an intermediate case between these two extremes.

The determination of the SUs took into account several parameters, including the historical constructive period, the variation of the interstorey height and corresponding alignments among 
portions, the vertical disposition of bearing masonry walls and thickness' changes, the typology of roof structures, the technological system adopted and, finally, the masonry typology determined through in-situ surveys [12, 17, 18].
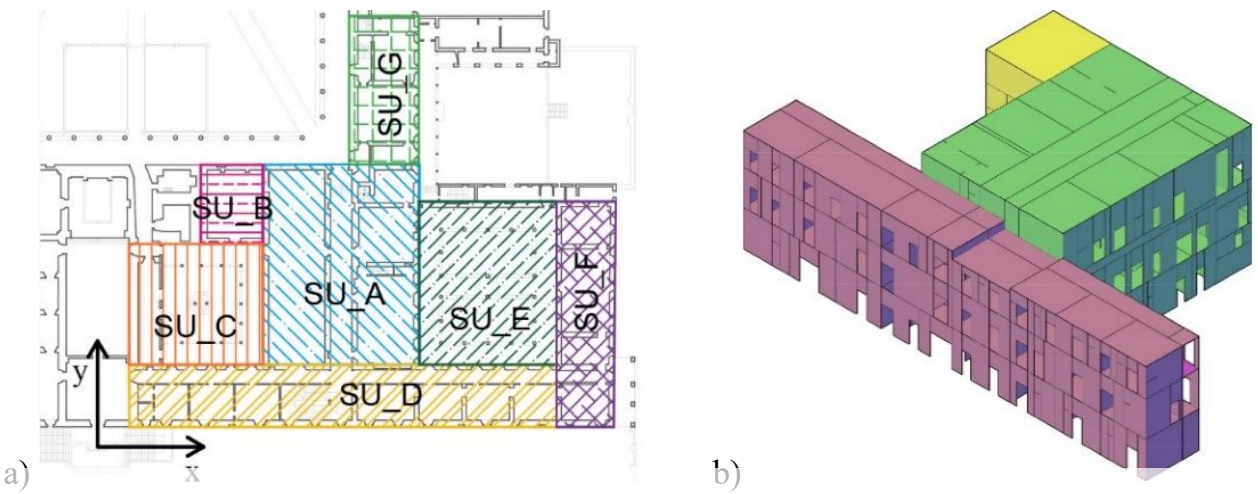

Figure 4: a) tag adopted for the different structural units identified inside the aggregate and indication of the reference system; b) 3D model showing the structural units so far analysed.

Due to the heterogeneity and complexity of the buildings investigated, it was almost impossible to achieve - even within each single SU - a perfect categorization according the listed parameters without reaching an excessive subdivision that would be not really representative of the effective structural behaviour. The pursuing of an 'overall' homogeneity was then preferred. based on the knowledge identification of at least

So far, only the thrt

differences among then period, even if the construction building reached
different SUs in
Js represented
wo units SU_A
may not be ex thanks to in-situ furveys. This choice
he considered area, as represented in
in Figure $4 \mathrm{~b}$ were analysed. Consi
and SU_B should belong to the sam
actly contemporary as suggested by a preferred,
led to the
Figure $4 a$.
idering the
historjcal
structural discontinuity identified in the ground floor. Moreover, SU_B is characterised by the presence of

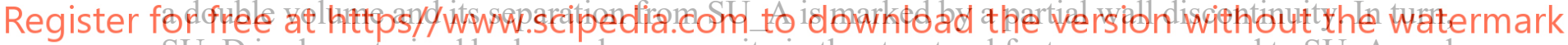
SU D is characterised by lesser homogeneity in the structural features, compared to SU_A, and by a strongly different spatial orientation. The separation between the two SUs is also marked by a different global height and by distinct roof structures.

\subsection{Numerical model}

A Finite Element Model (FEM) was built by means of the non-linear analysis software DIANA FEA [25]. For all the considered SUs, the same approaches were adopted.

Vaulted surfaces and horizontal floors were modelled as equivalent two-dimensional plane elements $[26,27]$ by using hexi-quadratic shell elements with eight (CQ40S) and six nodes (CT30S). The same typologies of elements were used to model also masonry walls, while threenode three-dimensional class-III beam elements (CL18B) were adopted for arches. Two-node enhanced-truss element (L6TRU) were used for ties and one-node point masses (PT3T) were employed to simulate the load distribution acting on walls in the case of beam-framed floors. The mesh size varied in proportion with the smallest dimension of each element, with a medium size of $50 \mathrm{~cm}$. Since no specific investigations were performed concerning the foundation system and the soil typology, vertical elements were fully restrained at the base.

For the constitutive model of masonry, the Total Strain Rotating Crack Model [25] was used, 
able to describe the nonlinear properties of the materials by assuming exponential softening in tension and parabolic hardening followed by softening in compression. The value of the tensile strength, where not directly provided by experimental tests or literature, was evaluated according to suggestions provided by $[26,27]$, starting from the compressive strength value. The compressive and tensile fracture energy, needed as input parameter in the numerical model, were determined according to [27, 28]. For wooden floors and vaulted structures, a linear elastic orthotropic material model was assumed. The mechanical characteristics were determined according to the principles of equivalence in axial stiffness [29, 30]. For steel components, a linear elastic material model was adopted.
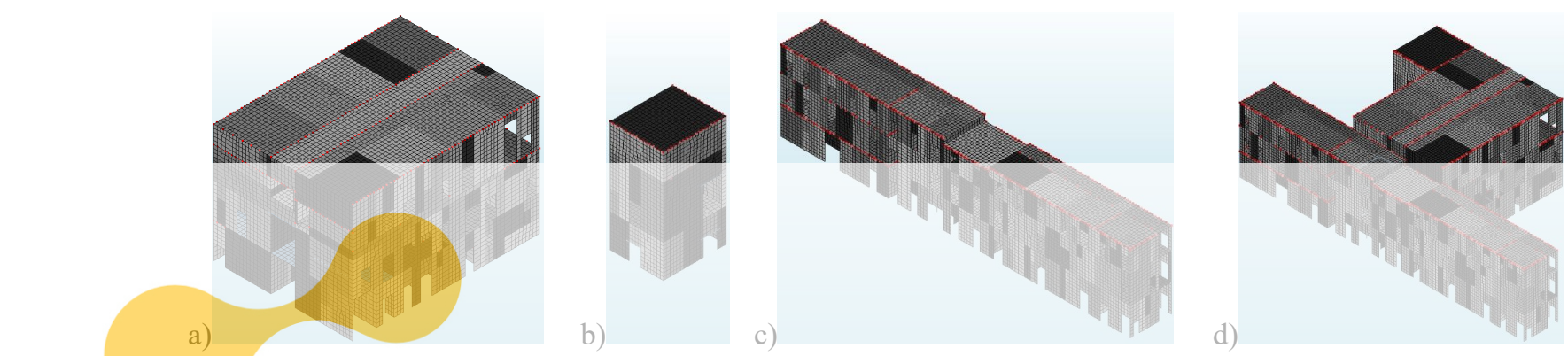

Figure 5: FEM model of Structural Unit SU_A, SU_B, SU_D, SU_A+B+D, respectively in a, b, c and d.

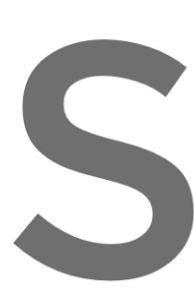

\subsection{Non-linear static}

The seismic perform analysis. While keeping

proportional to the mass

Each of the modelle
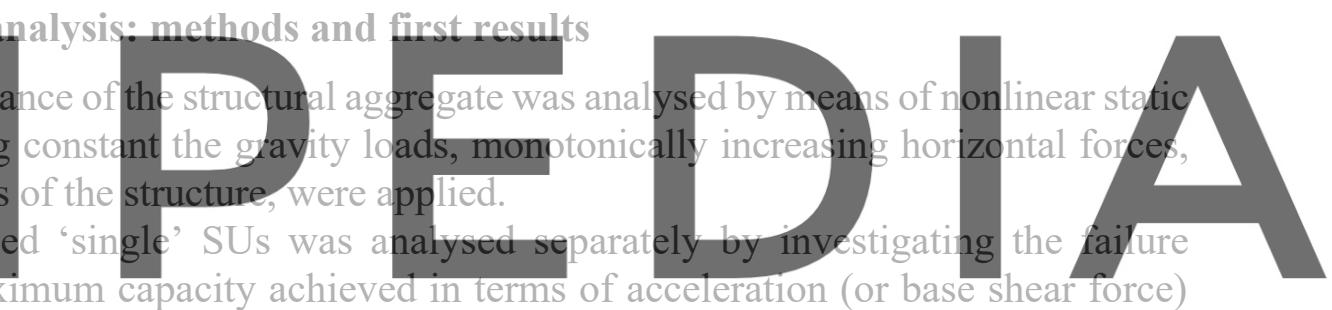

modalities and the maximum capacity achieved in terms of acceleration (or base shear force) and displacement. The single-unit analysis allowed an understanding of the individual

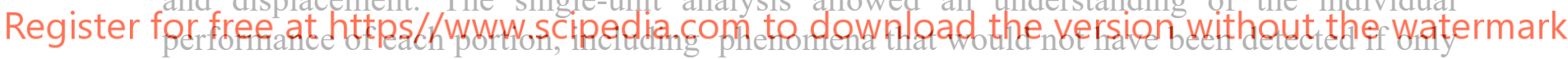
a global analysis of the entire aggregate had been performed (i.e. local failures, cracking and activation of out-of-piane phenomena of singie wails).

a)

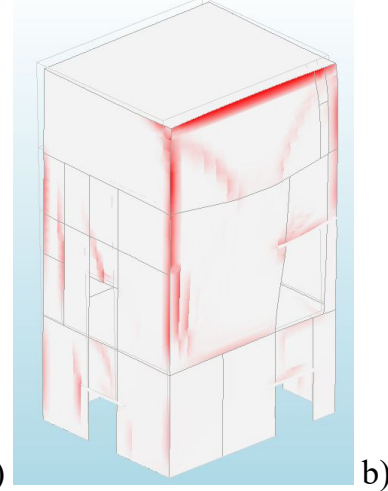

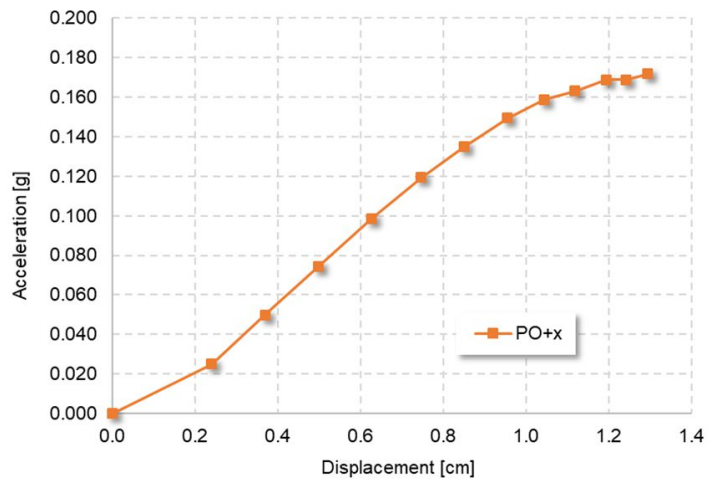

Figure 6: Pushover results for the $+x$ direction: a) tensile strain distribution and b) capacity curve.

As an example, Figure 6a shows the damage distribution due to an out-of-plane local 
mechanism for pushover analysis in +x direction on the structural unit SU_B (Figure 4) composed by a double volume. Figure $6 \mathrm{~b}$ shows the corresponding capacity curve. The same procedure was repeated for all the considered SUs.
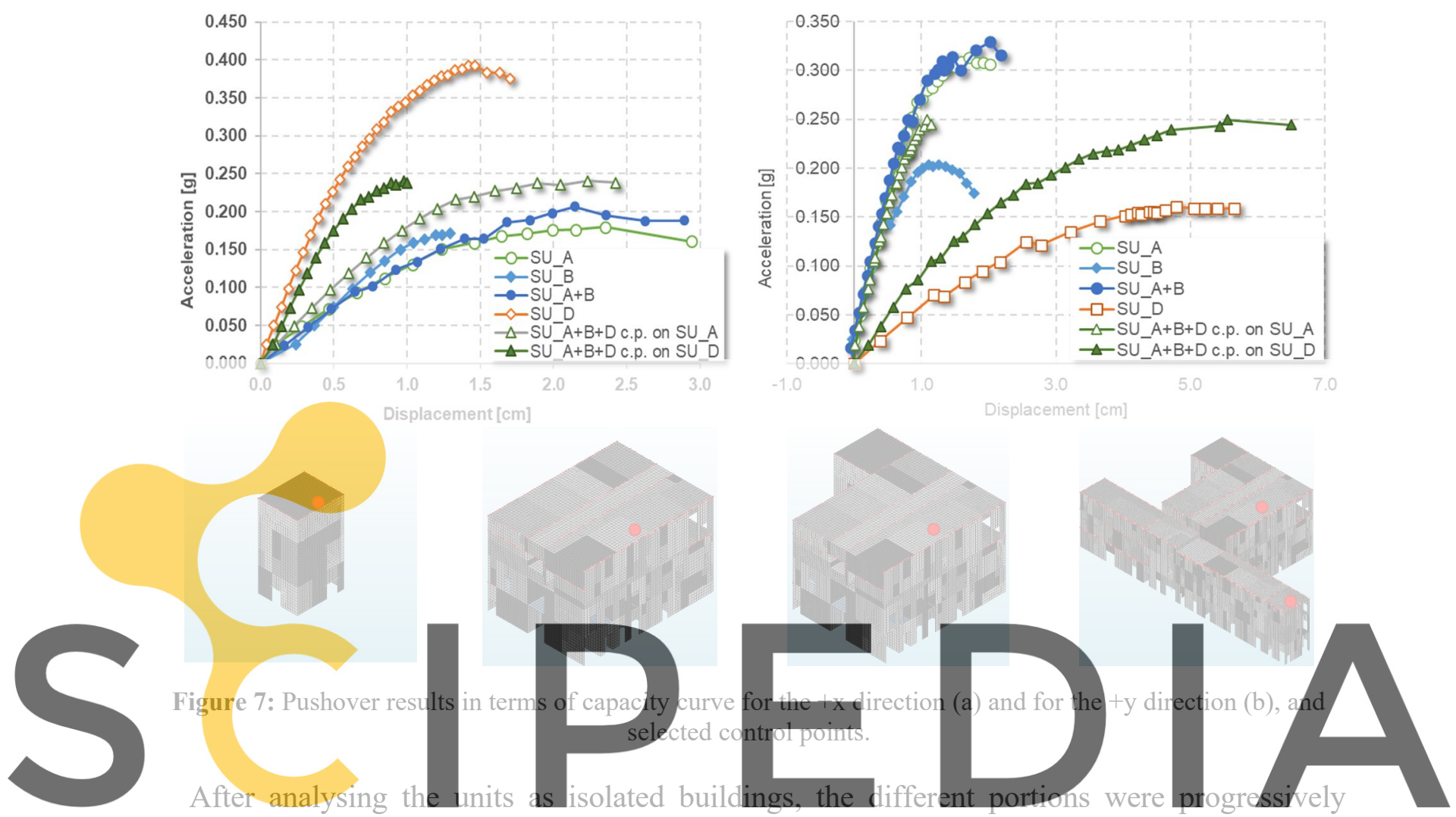

connected to each other with the aim of investigating the resulting behaviour due to the "in-

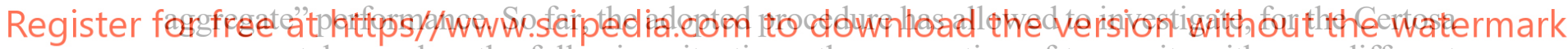
monumental complex, the following situations: the connection of two units with very different size and the connection of two units with very different shape. In the former case - SU A and SU_B - the units were characterised by different capacity related primarily to their dimensions but also to some local phenomena influencing on their performance. In the aggregate configuration, the capacity in $+y$ and $-y$ direction was approximately the same as for the larger unit. Less predictable was the result in $+x$ and $-x$ since the aggregate showed a rather higher capacity than the bigger unit. The smaller unit in fact, despite its limited dimension, was able to mitigate a short pillar effect which was affecting the capacity of the other unit in the isolated configuration. This local phenomenon took place near the connection among the two structures, in a wall of the larger unit which continues in the other one. Consequently, due to the particular location of the local phenomenon, including the smaller unit had a beneficial effect and increased the global capacity.

In the second analysed case - SU_A+B and SU_D - the two units considered as isolated were characterised by higher structural performance in opposite directions due to the very different shape with subsequent different stiffness and resistance. The aggregate configuration revealed, in all the directions, an intermediate capacity among those units analysed as single buildings. Due to their similar dimension, none of the two units was thus able in determining the structural 
performance of the aggregate. However, they mutually improved their capacity along the respective weakest directions. This result has been useful also to prove that in these two units the behaviour is not determined by local failures, as otherwise any increment of the global performance would have been hindered by them.

Figure 8 shows the comparison among damage distribution in different SU configurations for comparable accelerations. Cracks development in the connection between the two units can be noticed. Generally, differences in the damage distribution in proximity with the connection area were detected only when the pushover direction was parallel to the connecting surface.

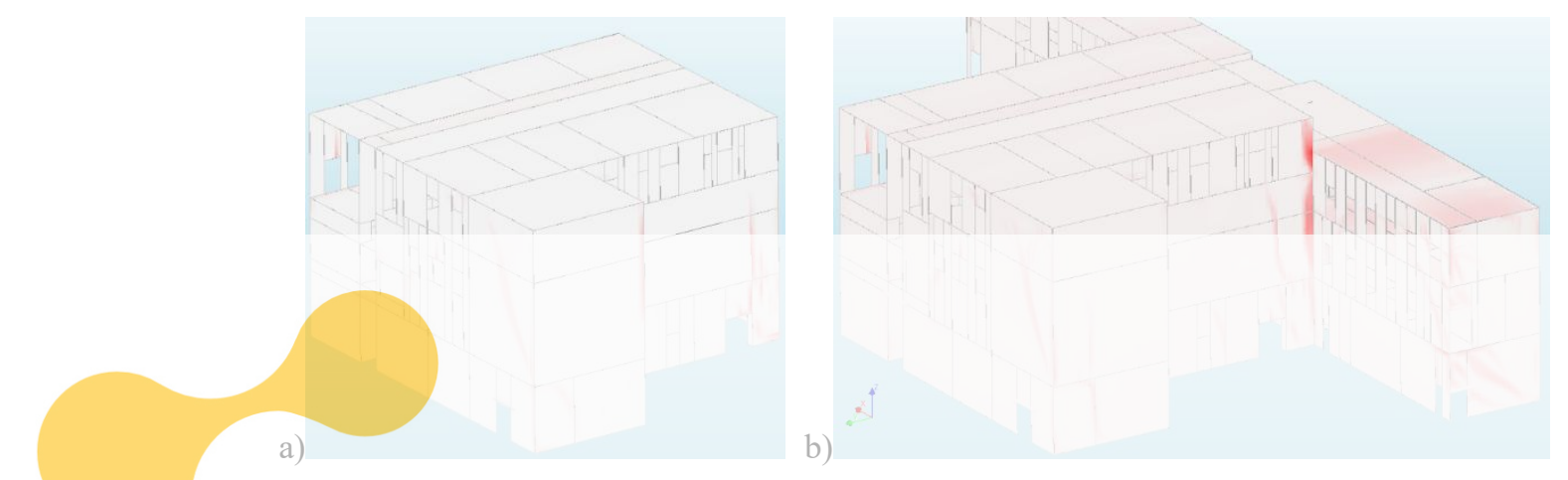

Figure 8: Difference in tensile strain distribution among the structural aggregate composed by SU_A+B (a) and the ones composed by SU_A+B+D (b)

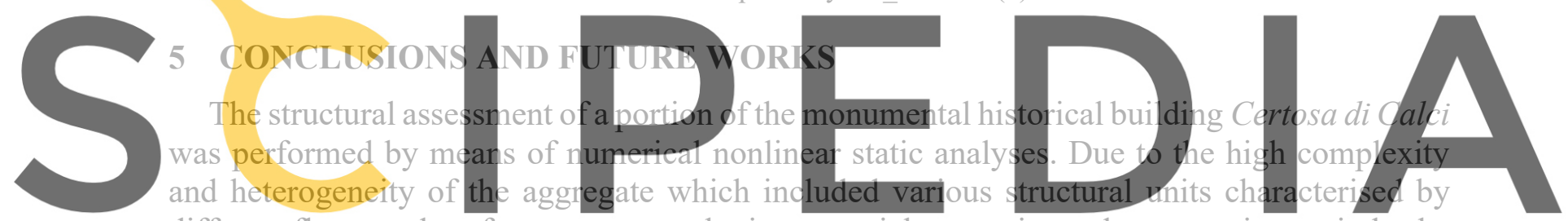

different floors and roofs, masonry typologies, material properties and construction periods, the

Register for free at https/Nwww.Scipedia.com to downitoad the version without the watermark constituting it. The interaction phenomena arising from the combination of the SUs were investigated through the analysis of different historical configurations with increasing complexity. The structural assessment was preceded by a deep multidisciplinary investigation allowing an adequate level of knowledge of the aggregate.

Different SUs were identified and 'extracted' from the monumental complex and their individual seismic response was investigated by means of FEM analyses. In a second phase, the units were progressively connected and pushover analyses were performed for each aggregation in order to study the failure modalities, the interaction phenomena and the modification of the seismic capacity due to the in-aggregate behaviour. It has been noticed that these kinds of analyses, even if oriented to understand the aggregate effect, should consider possible local mechanisms and the reciprocal influence of connected units in the overall behaviour. This phenomena in fact, could partially affect the result even when the structure is characterised by a global behaviour.

Further research is ongoing with the aim of considering a higher number of structurally connected units and also different connection levels among them.

Acknowledgements. The authors are thankful to the Pisa University and to the Superintendence 
BAPSAE of Pisa and Livorno for supporting and encouraging this research. The authors would like to thank Prof. M.G. Bevilacqua and his research team for the execution of the Laser Scanner survey, Prof. A. De Falco and her co-workers for the elaboration of the point clouds in CAD environment, for the experimental tests performed on chains and for the collaboration during the in- situ investigations. A special thank is also given to the expert technicians of the Laboratorio Ufficiale per le Esperienze sui Materiali da Costruzione of Pisa University for the execution experimental investigations. Finally, the authors' gratitude goes to Guglielmo Giambartolomei for providing the aerial photos of the Certosa di Calci.

\section{REFERENCES}

[1] Lagomarsino, S. On the vulnerability assessment of monumental buildings. Bulletin of Earthquake Engineering. (2006), 4, 445-63.

[2] Clementi, F., Gazzani, V., Poiani, M., Lenci, S. Assessment of seismic behaviour of heritage masonry buildings using numerical modelling. Journal of Building Engineering. (2016), 8, 29-47.

[3] Caprili, S., Puncello, I. Knowledge-Based Approach for the Structural Assessment of Monumental Buildings: Application to Case Studies. Front. Built Environ. (2019), 5, 52.

[4] Lagomarsino, S., Cattari, S., Degli Abbati, S., Ottonelli, D. Seismic assessment of complex monumental buildings in aggregate: the case study of Palazzo del Podestà in Mantua (Italy). In: SAHC2014- 9th international conference on structural analysis of historical constructions, Mexico City, Mexico, (2014), pp. 14-7.

[5] Caprili, S., Mangini, F., Salvatore, W. Numerical modelling, analysis and retrofit of the historical masonry building "La Sapienza". In: COMPDYN 2015, 5th ECCOMAS Thematic Conference on Computational Methods in Structural Dynamics and Earthquake Engineering, Crete Island, Greece, (2015), pp. 772-87.

[6] Cattari, S., Degli Abbati, S., Ferretti, D., Lagomarsino, S., Ottonelli, D., Tralli, A. Damage assessment of fortresses after the 2012 Emilia earthquake (Italy). Bulletin of Earthquake Engineering. (2014), 12, 2333-65.

[7] Castellazzi, G., D’Altri, A.M., de Miranda, S., Chiozzi, A., Tralli, A. Numerical insights on the seismic behavior of a non-isolated historical masonry tower. Bulletin of Earthquake Engineering. (2018), 16, 933-61.

[8] Cattari, S., Lagomarsino, S., Bosiljkov, V., D’Ayala, D. Sensitivity analysis for setting up the investigation protocol and defining proper confidence factors for masonry buildings. Bulletin of Earthquake Engineering. (2015), 13, 129-51.

[9] Caprili, S., Mangini, F., Paci, S., Salvatore, W., Bevilacqua, M.G., Karwacka, E., et al. A knowledge-based approach for the structural assessment of cultural heritage, a case study: La Sapienza Palace in Pisa. Bulletin of Earthquake Engineering. (2017), 15, 4851-86.

[10] Berto, L., Doria, A., Faccio, P., Saetta, A., Talledo, D. Vulnerability Analysis of Built Cultural Heritage: A Multidisciplinary Approach for Studying the Palladio's Tempietto Barbaro. International Journal of Architectural Heritage. (2017), 11, 773-90.

[11] Degli Abbati, S., D'Altri, A., Ottonelli, D., Castellazzi, G., Cattari, S., Miranda, S., et al. Seismic assessment of interacting structural units in complex historic masonry constructions by nonlinear static analyses. Computers and Structures. (2018).

[12] Binda, L., Cardani, G., A, S., Valluzzi, M., Munari, M., Modena, C. Multilevel Approach to the Vulnerability Analysis of Historic Buildings in Seismic Areas Part 1: Detection of 
Parameters for Vulnerability Analysis through on Site and laboratory Investigations, Restoration of Buildings and Monuments, (2007) 13(6), pp. 413-426

[13] Valluzzi, M., Munari, M., Modena, C., Binda, L., Cardani, G., A, S. Multilevel Approach to the Vulnerability Analysis of Historic Buildings in Seismic Areas Part 2: Analytical Interpretation of Mechanisms for Vulnerability Analysis and Structural Improvement, Restoration of Buildings and Monuments, (2007) 13(6), pp. 427-442

[14] Carocci, C.F. Small centres damaged by 2009 L'Aquila earthquake: on site analyses of historical masonry aggregates. Bulletin of earthquake engineering. (2012), 10, 45-71.

[15] Monti, G., Vailati, M. Analisi di vulnerabilità sismica di edifici in aggregato: un caso esempio. XIII convegno ANIDIS L'ingegneria Sismica in Italia. (2009), 28.

[16] Munari, M., Valluzzi, M., Cardani, G., Anzani, A., Binda, L., Modena, C. Seismic vulnerability analyses of masonry aggregate buildings in the historical centre of Sulmona (Italy), (2010).

[17] Formisano, A., Mazzolani, F., Florio, G., Landolfo, R. A quick methodology for seismic vulnerability assessment of historical masonry aggregates. In: Proc. of the COST Action C26 Final Conference Urban Habitat Constructions under Catastrophic Events, (2010), pp. 577-82.

[18] Vicente, R., Parodi, S., Lagomarsino, S., Varum, H., Silva, J.A.R.M. Seismic vulnerability and risk assessment: case study of the historic city centre of Coimbra, Portugal. Bulletin of Earthquake Engineering. (2011), 9, 1067-96.

[19] Aristo, M. La Certosa di Pisa. Mariotti, (1911).

[20] Piombanti, G. La Certosa di Pisa e dell'isola di Gorgona. Fabbreschi, (1971).

[21] Circolare. Istruzioni per l'applicazione dell'«Aggiornamento delle 'Norme tecniche per le costruzioni'» di cui al decreto ministeriale 17 gennaio 2018. In: 7, 21/01/2019.

[22] Coli, M., Livi, E., Tanini, C. Pietra Serena mining in Fiesole. Part III: Structuralmechanical characterization and mining. Journal of mining Science (2006), 42, 74-84.

[23] Cantisani, E., Garzonio, C., Ricci, M., Vettori, S. Relationships between the petrographical, physical and mechanical properties of some Italian sandstones. International Journal of Rock Mechanics and Mining Sciences (2013), 60, 321-32.

[24] CNR, D. 206/2007 Istruzioni per la progettazione, l'esecuzione ed il controllo delle strutture di Legno, (2008).

[25] TNO, D. DIsplacement method ANAlyser. User's manual, release 10.3. Netherlands, (2019).

[26] Lourenço, P.B., Barros, J., Oliveira, J.T. Shear testing of stack bonded masonry. Construction and Building Materials. 2004, 18, 125-32.

[27] Lourenço, P.B. Recent advances in masonry modelling: micromodelling and homogenisation. In: Multiscale modeling in solid mechanics: computational approaches, World Scientific, (2010), pp. 251-94.

[28] Drougkas, A., Roca, P., Molins, C. Numerical prediction of the behavior, strength and elasticity of masonry in compression. Engineering Structures (2015), 90, 15-28.

[29] Cattari, S., Lagomarsino, S., Resemini, S. Il ruolo delle volte nella risposta sismica degli edifici in muratura. Archi e volte in zona sismica-Meccanica delle strutture voltate. Doppiavoce, Naples, (2012).

[30]Wilson, A., Quenneville, P.J., Ingham, J.M. In-plane orthotropic behavior of timber floor diaphragms in unreinforced masonry buildings. Journal of Structural Engineering. (2013), 140,04013038 . 